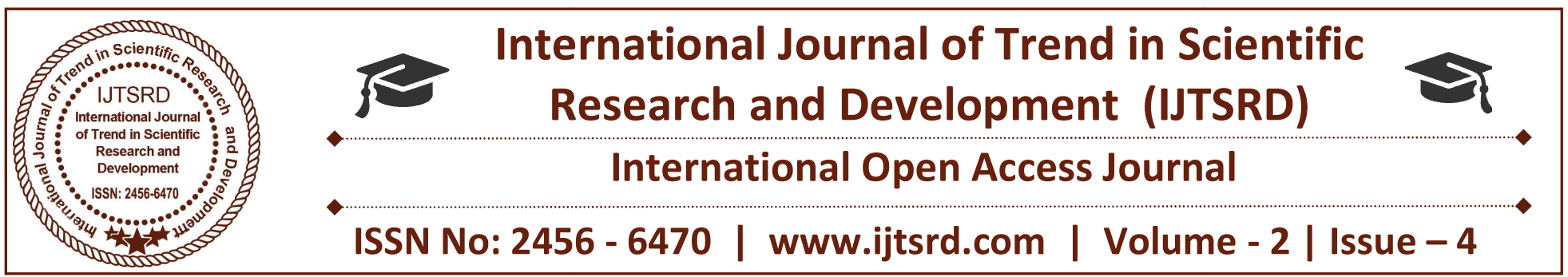

\title{
Philosophical Thoughts as Reflected in Drama-S of Kālidāsa
}

\author{
Dr. Debajyoti Jena \\ Head of the Department, Department of Sanskrit \& Indian Culture SCSVMV University, \\ Enathur, Kanchipuram, Tamil Nadu, India
}

Mahākavi Kālidāsa a luminous star in the galaxy of Sanskrit literature. As a poet as well as a Dramatist, he has not only written the prominent poems and famous dramas just for the amusement and happiness for the people of society, but he has reflected the socio-political status, religious thoughts and spiritual approaches of the society as well. It is also noticed that when Sanātanadharma or Vaidikadharma once upon a time was in crises by the influence of Buddhadharma and Jainadharma in the soil of India, by the mean time, Ancient Scholar (Vaidika Rși) have made their efforts to establish and propagate the same by highlighting the value of it. Establishment of Dharma was only possible through the writing of Kāvyas and Nätakas by the then scholars. As a result, poet Kālidāsa has not ignored the chance to highlight the concept of philosophy and religion, while writing his dramas and poems. We may discuss here few areas where Kâlidāsa has concentrated to highlight the philosophical thoughts in his writings particularly in dramas.

Moreover, the establishment of Iśvaravāda, the concept Prakrti and Purușa, Yogavichāra, Iśvaratattvasidhanta, Vāgarthavāda and the concept of Yajn̆a and Devatā are discussed in detailed in this research paper with proper evidences.

\section{Establishment of İśvaravāda}

It is also observed that, after a long gap of time duration, the Vedic Gods like Aśvinkumār, Indra, Agni and Kubera were not worshiped, in their place Brahmā, Viṣnu and lord Śiva became so popular among the people during the Kālidāsian period. Most probably due to the influence of Buddhism, the worshipers of different Gods became united by leaving their diversity. By noticing this and being a strong devotee of Śiva, poet Kālidāsa made Śivastuti in his drama Mālavikāgnimitram with eightfold image of Lord Śiva in Mangalācaranam.

He proclaims the worship of all pervaded Lord Śiva lends human for attainment of knowledge by removing the ignorance. It is said rightly-

एकैश्वर्ये स्थितोपि प्रणतवहुफले यः स्वयं कृत्तिवासाः।

कान्तासम्मिश्रदेहोडप्यविषयमनसां यः पुरस्ताद्यतीनाम्।। अष्टाभिर्यस्य कृत्त्रं जगदपि तनुभिर्बिभ्रतो नाभिमानः।

सन्मार्गालोकनाय व्यपनयतु स वस्तामसीं वृत्तिमीशः।। Mālavikāgnimitra -1.1

In the above said Mangālācaranam, poet Kālidāsa has very carefully used a term as "Kantāsammiśradeha", which represents Devī Pārvatī with lord Śiva. It is also denoting the Ardhanāriśvara concept of Lord Siva and Pārvatī. In Raghuvamsa (1.1) while he used 'Vāgarthau', in connection to that, he also used a term as 'Samprktou', which means both Lord Śiva and Pārvatī are in separable in their way. So it is understood that Kālidāsa has not used the term 'Samyuktou' in state of 'Samprktou'. It means, if he could have written the term 'Samyuktou', in that case there could have possibility to get separation of Siva and Pārvatī but the term 'Samprktou' denotes a strong bond between Śiva and Pārvatī which is inseparable. By realising this, Poet Kālidāsa has also explained the Mangalācaranam of Mālavikagnimitram by using the term 'Sanmiśradeha' to represent the term 'Samprkta' and established the concept of Ardhanāriśvara.

The same concept is also reflected in Nandi of Abhijn̄ānaśäkuntalam to strengthen more. To get rid of form the rebirth or Punarjanma, Kālidāsa also 
prayed Lord Śiva in Bharatvākya of Abhijn̄ānaśākuntalam.

\section{ममापि स क्षपयतु नीललोहितः}

पुनर्भवं परिगतशक्तिरात्मभू:॥। Abhijňānaśākuntalam- 7.35

Further, it is understood when Buddhists had established the concept of Niriśvaravāda and the whole society was in wrong direction, by the mean time, perhaps Kālidāsa was trying to establish Iśvaravāda by throwing light towards the eightfold images of Lord Siva.

\section{Concept of Puruṣa \& Prakṛti :-}

Bṛhadāranyakopanișad says "एकमेवाद्वितीयम् ब्रह्म नेह नानास्ति किश्चन". This statement is also supported by Nāsadīyasūkta (10-29) of Rgveda proclaiming that supreme Brahman is one in form there is no duality. This is to be called as Ekattavāda. If we have a deep vigil towards the Kālidāsian Society, we understood that, the concept of Dvaita or Dvaita Siddhānta was also prevailing in the then society and taking the form or line of special Śāstra. The most prominent and oldest darśana is Sānkhyadarśana among the Saddarśana. We may get its tremendous impact on Bhagavatgitā. This Sānkhya philosophy l'accepts Purusatattva, there is no doubt in it, but it also accepts the Prakrtitattva as eternal along with Purușatattva.

It is understood that, the concept of Purusa and Pakrti or we may say Prakrtipurușavāda was so powerful and sway during Kālidāsiān age. As a result, the entity of Prakrti and Purusa was well treated in the form of Pārvatī and Parameśvara. Kālidāsa has nicely narrated in Raghuvamsa as 'Vāg' and 'Artha' by representing Pärvati and İ́vara. The same idea is also reflected in Manalācaranam of Mālavikāgnimitram and poet used the term Sammiśradehah as already discussed earlier.

\section{Yogavicārạ̣ :-}

Poet Kālidāsa has taken the term Puruṣa from the definition of Sānkhyśattra and the term Yoga and Samādhi from the definition of Yogasütra. Not only in the Drāmas but also in his poems, he has frequently used the term from Sankkhy Philosophy and from Yogasūtra. Maharshi Patanjali says in Yogasūtra as ईश्वरप्रणिधानाद् वा, it means the Devotion towards Ísvara many led to Mukti or Mokșa to the Devotees. Here in this Sūtra, Patanjali did not use the term Brahma but used the term as İ́vara. In Mangalācarana of Abhijn̄ānaśākuntalam, Kālidāsa used the term Iśa. "ईश् सत्तायाम्" means the master of the whole universe (ब्रह्माण्ड) is Ísvara. If we see in general, Brahma has no connectivity with Brahmānda. So in this connection, both Patanjali and Kālidāsa accept the entity of İ́sa in Brahmānda. That why Kālidāsa understood the eight fold images of Ísvara which is all-pervading in the whole universe. As Kālidāssa says-

\section{प्रत्यक्षाभिः प्रपन्नतनुभिरवतु वस्ताभिरष्टाभिरीशः।।} Abhijn̄ānaśākuntalam -1.1

Here Kālidāsa has used the term Pratyakșa intentionally to show his response towards the Śunyavāda of Baudhadarśana. As a result Kālidāsa wanted to prove Íśvara who is Nirākāra, Nirvikalpa, Nisarga, Nirdvanda, Nirupamavibhava and Paramacaitanya as per the line of Yogadarśana.

Again it is also said that Ísvara of Patanjali and Purușa of Sänkhya had no connectivity with Yogasūtra of Patanjali but Kālidāsa has made both in one. In the Mangaläcaranam of Vikramorvasiyam he says:-

वेदान्तेषु यमाहुरेकपुरुषं व्याप्य स्थितं रोदसी

यस्मिन्नीश्वर इत्यनन्यविषयः शब्दो यथार्थाक्षरः।

अन्तर्यश्च मुमुक्षुभिर्नियमितप्राणादिभिर्मृग्यते

स स्थाणुः स्थिरभक्तियोगसुलभो निःश्रोयसायाउस्तु वः।। Vikramorvasiyam -1.1

It is to be marked that Kālidāsa has used the term sthirabhaktiyogasulabha (स्थिरभक्तियोगसुलभ) in last line as an adjective to Sthānu is nothing but the Sagunarupa of Lord Śiva. We understand that Patanjali has directed two ways to achieve Mokșa.

$>$ A Yogi gets or realises Atmā through Contemplation can achieve Mokșa.

A Devotee keeps attention through Devotion toward İ́vvara can also achieve Mokșa.

In this Mangalācaraṇa, Kālidāsa used the term Sthānu by keeping the idea of Patanjali as "ईश्वरप्रणिधानाद् वा". Sthira means concentration or Ekāgratā. A devotee should have concentration on Iśvara like a Yogi. That concentration is Ananyabhakti. Through Ananyabhakti, a devotee will get stability or Sthiratā. Kālidāsa accepts the concentration or Ekāgrata of Yogi in case of a Devotee. The term $v \bar{a}$ (वा) is represents as Vikalpa or substitute, means the second path Bhaktiyoga may be adopted to achieve Mokșa alternatively. Therefore Kālidāsa has accepted Sthirabhaktiyoga through the 
control of Chittavrtti. As Patanjali defines the Yoga योगश्चितवृत्तिनिरोधः. Again here the term İ́varapanidhâra denotes as Bhakti to concentrate on Ísvara to get Mokș. This is the Yogavicara or yogic concept which has been taken by Kālidāsa and reflected the same in his Drāma Vikramorvaśíyam.

\section{İ́saratattvasiddhānta :-}

To understand the thoughts of poet Kālidāsa, we must accept the contribution of Maharși Patanjali. Yogadarśana of Maharși Patanjali was standing like a milestone before the Vedic \& Buddhist thoughts. Maharși Patanjali has explained and defined the Samädhitattva and also accepted the same for Purușatattva as prescribed by Sänkhya philosophy. Once upon a time, the existence of Purusa was doubtful and the position of Prakrti became so prominent. As per Sānkhyadarśana, Purușa became Udāsina. By the mean time, there was a need to establish Ísvaratattva where as Patanjali proved to achieve Mokșa through Yogamärga. By getting influenced by Yogadarśana perhaps Kālidāsa has established the concept of Ísvara in his writings. As already we have discussed that, the Mangalācarana of the drama Mãlavikāgnimitram, Vikromorvasíyam and Abhijn̄assáakuntalam clearly denote the concept of İ́sara.

In Mālavikāgnimitram, poet Kālidāsa has explained the eightfold form of Lord Siva with association of Pārvatī by using the term Kāntāsammiśradeha. Again he has used the term Íśa to denotes Lord Śiva. In Vikramorvaśíyam and Abhijñānaśākuntalam also the concept of Ísvara is established by poet Kālidāsa.

\section{Vāgarthavāda :-}

Poet Kālidāsa was contemporary to Maharṣi Patanjali. When we analyse the concept of Śabda and Artha of Patanjali we may come across with many issues. In

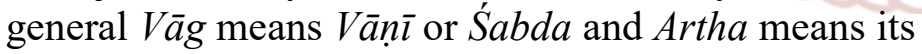
meaning. But apart from this, whatever the problem was occurred earlier to Kālidāsa on Śabda and Artha, by the time Poet, Kālidāsa was completely aware about it. During the period of Kālidāsa, Ālamkārikas also have given different opinion on Śabda and Artha in connection to Kāvya. Aștādhyāyi of Pānini was placed before the scholars as Śabdānuśāna and based on that, Patanjali has emphasised the importance of Śabda in his work Mahābhāṣya. In Sāhityaśāstra, Scholars also have given importance to Śabda. In this juncture, importance to the part of Artha, during that period might have neglected or influenced less. Such problem of Sabdārtha was properly understood by Kālidāsa.

It is also noted that, during Vedic period the concept of Śabdabrahma was the prime thought of Vedic Seers. Vedavākya-s are ultimate truth by giving importance to Śabda and these Śabdas are eternal. That's why Vedic Mantras are intact without having any changes there in, but in Laukika Sähitya there are different Pāthabhedas. Moreover, due to impact of Vedic tradition, scholars like Yāska, Pāninini, Patanjali have given more emphasis on Śabda. Thereafter, when Laukika Sähitya took its shape and scholars have started writing Kāvyas and importance of Artha came in contact with Sabda. It is rightly said that सिद्धे शब्दर्थयोर्नित्यसम्बन्धः it means in Kāvya, both Śabda and Artha are eternally connected each other to convey/a specific meaning. Accepting this view, Acārya Bhāmaha said "शब्दार्थौ सहितौ काव्यम्"to extend a beautiful definition of Kāvya. In this connection poet Kâlidāsa also had accepted this statement; as a result he has put his intention to mingle both in a poetic form in the Mangaläcarana of Raghuvamsa. As it is said-

वागर्थाविव सम्पृत्तौ वागर्थ प्रतिपत्तये।

जगतः पितरौ वन्दे पार्वतीपरेमेश्वरौ॥ Raghuvamsa- 1.1.

In this verse, Kālidāsa wants to convey the eternal connectivity between Lord Siva and Pārvatī, the divine parents of whole universe with a simile, like the relation between Śabda and Artha. The term Vāg means Śabda or Vạni and Artha means its meaning but here Kālidāsa has not used the term शब्दार्थाविव in place of वागर्थाविव deliberately. The term Vāg signifies the feminine nature as per grammatical rule which represents the Devī Pārvatī and the term Artha signifies the masculine nature, represents Lord Siva. Through the Vyañjana Vyapāra it is explained by Kālidāsa by emphasising Śabda and Artha are inseparable. This concept indirectly touched upon by Kālidāsa to establish the Ardhanāiśvara of the Divine Couple. By using Upamālankāra, Kālidāsa tries to intensify the Dhvanitatva as Śabda and Artha both are equally importance for a Kärya. Again he has represented the beauty (सौन्दर्य) of Dāmpatya Prema (Conjugal life) in form of Siva and Pārvatī and established the position of Śabda and Artha in Kävya. Here we may say, the Anurakti Saundarya between Śabda and Artha is also reflected. As long Śiva and Śakti cannot be separated like Śabda and Artha cannot be separated like the relation between Guna and Guni 
and Dharma and Dharmī. This is Saudaryavāda of Vāmana. Finally it may say, Poet Kālidāsa has explored the truth of Śabda and Artha in advaita form and made both united in the form of Ardhanāríśvara and also explained Astamurti form of Śiva in Vedāntic perspectives in his dräma-s.

\section{Concept of Yajňa \& Devatā :-}

If we have a glance to the religious thoughts of Kālidāsa through this writings, we may confined him to the age of $2^{\text {nd }}$ century B.C. Poet Kālidāsa tries to establish and support the Vaidika Dharma or Sanātana Dharma in his drāma-s. During Buddha and Jaina period Animal Violence was existing in Yajn̆a and performance of Bali was prevailing. Creating injury to the animals was considered as ill activities. Such reflection we may get in $6^{\text {th }}$ act of Abhijňānaśākuntalam through the dialogue of the fisherman. He proclaims that, due my Kaulikavrtti. I used to do ill activities everyday by catching fishes like a Pandita who used to provide Bali of Animal in Yajn̆a even though he does not like to do such cruel actives. It is said by Kālidāsa as -

\section{सहजं किल यदविनिन्दितम् न खलु तत्कर्म विवर्जनीयम्।}

पशुमारणकर्मदारुणोडनुकम्पामृदुरेव

श्रोत्रियः।1।

Abhijňānaśākuntalam 6.1

From this verse it is understood that killing or creating injury to the animals was considered as an ill and cruel activity during Kālidāsian period. After Buddha, Jaina and post period of Kālidāsa, killing animals in Sacrifice or Yajn̆a was prohibited due to the gradual impact of Bhaktimārga and Yogamārga. This Baliprath $\bar{a}$ or killing animal in Sacrifice was prevailing during Kālidāsian period because of the greater influence of King and Monarchy.

Apart from this, we may recognise the position of Heavenly Gods in Kālidāsian drāmas. When calamities occur, the kings of Kālidāsa were being invited by the Gods to assist them. In Vikramorvaśiyam,(1.6) through the dialogue of Menakā in first act we notice that, king Pururavā was invited by lard Indra to help him war against Dānavas. The exact reference also we may get in Seventh act of Abhijňānaśäkuntalam (7.1) where king Dusyanta was being invited by Indra and extended hospitality. The hospitality, which was extended to Dușyanta by Indra by offering a beautiful garland of Mandārapușpa. It is said in Abhijňānaśākuntalam-
अन्तर्गत- प्रार्थनामन्तिकस्थं जयन्तमुब्दीक्ष्य कृतस्मितेन। आमृष्ट- वक्षो हरिचन्दनाड्का मन्दारमाला हरिणा पिनद्धा ।। Abhijňānaśākuntalam - 7.2.

In Vikramorvaśīyam, after getting invitation from Indra, Pururavā indulged in war and put Daityas in to ocean by his powerful arrows. It is said-

\section{अदः सुरेन्द्रस्य कृतापराधान् प्रक्षिप्य दैत्यांल्लवणाम्वुराशौ।} वायव्यमस्रं शरधिं पुनस्ते महोरगः श्वभ्रमिव प्रविष्टम्।। Vikramorvaśīyam - 1.19.

Kālidāsa sometime utters the name of other Gods while composing drāmā-s. In Vikramorvaśíyam he utters the name of Brahmā, when explaining the extra ordinary beauty of Urvasī. He says-

वेदभ्यास ज़ड: कथन्तु विषय- व्यावृत कौतूहलो।

निर्मातुं प्रभवेन्मनोहरमिदं रूपं पुराणो मुनिः।। Vikramorvaśíyam-1.10.

In Mālavikāgnimittram, Kālidāsa explains the name of Viṣnu who has sifted Rukminī and got marry her. Kālidāsa says-

तव हृतवतो दण्डानीकैर्विदर्भपतेः श्रीयम्।

परिधगुरुभिर्दोर्भिर्विष्णोः प्रसह्य च रुक्मिणीम्।।

Mālavikāgnimitram- 5.2.

Again we also noticed that very frequently Kālidāsa utters the name of Siva in Mangalācaranam of all three drāma- $S$ as critics described him as a Śaiva- a great believer of Sivatattva.

Finally, in this research paper an attempt has been made to establish the philosophical thoughts as reflected in the dramas of the great poet Kālidāsa.

\section{References -}

1. Mahākavi Kālidāsa - Dr. Prabhu Dayal AgnihotriEastern Book Linkers, Delhi, 1997

2. Kālidāsa Vyakti tathā Abhivyakti- Dr.Prabhākar Narayan Kavathekar- Nag Publication, Delhi,2009

3. Kālidāsa - Dr. V.V. Mirashi - Popular Prakashan, Bombay -1969

4. Kālidāsa : Afresh - Prof. Satya Pal Naranga, Nag Publisher, Delhi- 1997

5. Works of Kālidāsa - C.R. Devadhar - Motilal Banarasidass, Delhi- 1984

6. Kālidāsa - A critical study- Dr. A.D. SinghBharatiya Vidya Prakashan, Delhi -1976 